Justifying Genocide 



\section{Stefan Ihrig}

\section{Justifying Genocide}

Germany and the Armenians from Bismarck to Hitler

\section{Harvard University Press}

Cambridge, Massachusetts, and London, England 2016 
Copyright $\odot 2016$ by the President and Fellows of Harvard College All rights reserved

Printed in the United States of America

\section{First printing}

Cataloging-in-Publication Data available from the Library of Congress ISBN: 978-0-674-50479-0 (alk. paper) 
To my wonderful wife, Roni, with whom everything makes a little bit more sense 
